\title{
Penerapan Sistem Manajemen Mutu ISO 9001: 2015 di SMK Negeri 4 Banjarmasin
}

\author{
Fitria Wulandari ${ }^{1 *}$, Zainal Arifin ${ }^{2}$, Subiyantoro $^{3}$, Sedya Santosa ${ }^{4}$ \\ ${ }^{1234}$ Universitas Islam Negeri Sunan Kalijaga, Yogyakarta, Indonesia \\ 120204091001@student.uin-suka.ac.id
}

\begin{abstract}
This study aims to find out 1) What are the stages of implementing the ISO 9001:2015 quality management system at SMK Negeri 4 Banjarmasin and 2) What is the impact of implementing the system on the work system and work culture in schools. This research is a field research with a qualitative descriptive approach. The process of collecting data was carried out by observing, then interviewing the Deputy Principal for Quality Management and equipped with some documentation. The data analysis that the researcher uses with the Miles and Huberman Model is condensation, data presentation and conclusions/verification. The results of this study indicate that: 1) several stages carried out by SMK Negeri 4 Banjarmasin in implementing the ISO 9001:2015 quality management system are a) attend training with the guidance of a consultant, b) prepare quality documents and implement a quality management system according to documents prepared by the school, c) internal audit coordinated by the Quality Management Deputy, d) external audit conducted by PT. URS Service Indonesia, and e) granting of ISO 9001:2015 certificate/Institutional certification. The impact of the implementation of ISO 9001: 2015 is the creation of a better work system, organized according to procedures and can create a team work culture that upholds solidarity and work professionalism.
\end{abstract}

Keywords: Implementation of ISO 9001:2015, Standard Quality Procedures, Risk Management

\begin{abstract}
Abstrak. Penelitian ini bertujuan untuk mengetahui 1) Bagaimana tahapan penerapan sistem manajemen mutu ISO 9001: 2015 di SMK Negeri 4 Banjarmasin dan 2) Bagaimana dampaknya dari penerapan sistem tersebut terhadap sistem kerja dan budaya kerja di sekolah. Penelitian ini merupakan penelitian lapangan dengan pendekatan deskriptif kualitatif. Proses pengumpulan data dilakukan dengan melakukan observasi, kemudian wawancara dengan Wakil Kepala Sekolah bidang Manajemen Mutu dan dilengkapi dengan beberapa dokumentasi. Adapun analisis data yang peneliti gunakan dengan Model Miles and Huberman yakni kondensasi, penyajian data dan kesimpulan/verifikasi.Hasil dari penelitian ini menunjukkan bahwa: 1) beberapa tahapan yang dilaksanakan oleh SMK Negeri 4 Banjarmasin dalam penerapan sistem manajemen mutu ISO 9001: 2015 adalah a) mengikuti pelatihan dengan bimbingan konsultan, b) penyiapan dokumen mutu dan pelaksanaan sistem manajemen mutu sesuai dokumen yang telah dibuat oleh pihak sekolah, c) audit internal yang dikoordinir oleh Wakil Manejemen Mutu, d) audit eksternal yang dilakukan oleh PT. URS Service Indonesia, dan e) pemberian sertifikat ISO 9001: 2015/ Sertifikasi lembaga. Adapun dampak dari penerapan ISO 9001: 2015 terciptanya sistem kerja yang lebih baik, tertata sesuai prosedur dan dapat menciptakan budaya kerja tim yang menjunjung tinggi solidaritas dan profesionalisme kerja.
\end{abstract}

Kata Kunci: Penerapan ISO 9001: 2015, Standar Prosedur Mutu, Risk Management.

\section{PENDAHULUAN}

Bangsa yang satu dan yang lainnya di era globalisasi ini semakin dituntut untuk menyelenggarakan pendidikan yang bermutu dan mampu berdaya saing, hal itu karena jika mutu pendidikan tidak menjadi hal yang prioritas 
untuk terus ditingkatkan akan sangat berpengaruh dan menjadi problematika bagi sebuah bangsa. Dalam peningkatan mutu di lembaga pendidikan semua pihak sekolah atau seluruh stakeholders harus mendukung dan bekerjasama melalui pendekatan struktural maupun kultural (Yasin, 2021). Problematika mutu di lembaga pendidikan saling terkait dan mempengaruhi satu sama lain, mulai dari input/masukan yang akan berpengaruh terhadap proses dan proses yang akan mempengaruhi output/keluaran begitupun sebaliknya (Suryana, 2020).

Lembaga pendidikan memiliki peran yang sangat penting dalam melahirkan sumber daya manusia/output yang bermutu. Akan tetapi fakta dilapangan masih menunjukkan bahwa capaian sumber daya manusia di lembaga pendidikan di Indonesia belum memenuhi standar internasional (Suryana, 2020). Menurut gambaran dari hasil studi internasional TIMSS, PISA, dan PIRLS, Indonesia masih berada di bawah skor rata-rata internasional (Tjalla, 2010). Hal tersebut menunjukkan bahwa perlu adanya peningkatan mutu dilembaga pendidikan di Indonesia guna melahirkan output yang berprestasi sesuai standarisasi hingga internasional.

Mengenai mutu dilembaga pendidikan, pimpinan sebagai puncak tertinggi sangat berperan untuk membentuk tim peningkatan mutu dan senantiasa melaksanakan perbaikan secara terus-menerus bersama seluruh stakeholders demi ketercapaian visi dan misi lembaga. Mutu dilembaga pendidikan tentu akan sangat berkaitan dengan sebuah sistem manajemen yang digunakan. Sekolah yang bermutu adalah sekolah yang mampu mengimplementasikan sistem manajemen sekolah yang baik, dengan terus berkomitmen untuk melakukan perbaikan secara berkelanjutan (Rizkita \& Supriyanto, 2020). Ada beberapa strategi yang dapat dilakukan kepala sekolah dalam meningkatkan mutu di lembaga pendidikannya yakni: merencanakan program-program dengan melibatkan tim, membuat struktur penanggungjawab setiap program, melakukan pengembangan sumber daya manusia melalui beberapa kegiatan pelatihan, juga senantiasa melaksanakan pengawasan terhadap input, proses dan output lembaga pendidikan (Wibowo \& Subhan, 2020).

Kepala sekolah selaku leader dan supervisor juga harus terus meningkatkan profesionalisme pendidik sekolah melalui berbagai kegiatan, hal tersebut dilaksanakan agar dapat memberikan pengaruh terhadap peningkatan mutu pendidikan di lembaga (Suwartini, 2017). Profesionalisme pendidik dapat terlihat dari peningkatan kompetensinya dengan didukung oleh faktor internal dan eksternal (Yunus, 2016) (Yanto \& Fathurrochman, 2019). Selain profesionalisme pendidik, peningkatan terhadap prestasi 
akademik dan non akademik siswa juga perlu untuk terus ditingkatkan dan dikembangkan agar peningkatan mutu secara berkelanjutan dapat terlaksana (Noprika et al., 2020).

Dalam hal peningkatan mutu lembaga tentunya terdapat aspek internal dan eksternal yang harus terpenuhi dan diperhatikan. Aspek yang paling mudah dijangkau dan bisa dijadikan sebagai sumber kekuatan adalah dari aspek internal lembaga dengan melaksanakan program-program unggulan yang bisa memberikan dampak yang baik terhadap pengembangan dan peningkatan mutu lembaga (Alfiansyah et al., 2020). Lembaga pendidikan tentu harus memperkirakan hambatan yang akan ditemui nantinya seperti keterbatasan anggaran, kurang sumber daya manusia, dan lain sebagainya. Namun, hambatan peningkatan mutu pendidikan di Indonesia sebenarnya tidak semata-mata berkenaan dengan anggaran yang terbatas, sarana prasarana yang kurang memadai maupun kurangnya jumlah sumber daya manusianya, tapi berkenaan dengan budaya dan sistem nilai yang dianut (Yasin, 2021).

Kenyataan tersebut menjadi kendala kultural yang menjadi sebab sejumlah kebijakan pemerintah yang cukup berpihak pada pendidikan seringkali tidak menunjukkan pengaruh signifikan terhadap peningkatan mutu pendidikan itu sendiri (Yasin, 2021). Indikator sekolah bermutu adalah adanya dukungan pemerintah, efektifitas pemimpin, profesionalisme pendidik, relevansi kurikulum, output berkualitas dan berdaya guna, efektifitas budaya dan iklim organisasi serta terdapat dukungan penuh dari orang tua siswa, semua indikator tersebut saling bersinergi dan berkontribusi (Fadli, 2017). Karena salah satu prinsip dalam penerapan sistem manajemen mutu ISO 9001: 2015 adalah prinsip keterlibatan orang (Muryadi et al., 2018).

Penerapan sistem manajemen mutu ISO 9001 merupakan cara yang tepat dalam peningkatan mutu dilembaga pendidikan. Berdasarkan perspektif Islam menyatakan bahwa manajemen mutu adalah mutu yang bisa dikatakan sebagai bentuk kesesuaian antara fakta "sesuai dengan keadaan yang ada" artinya sesuai dengan standar yang telah direncanakan dan ditetapkan di lembaga tersebut. Kesesuaian inilah dalam manajemen mutu pendidikan menjadi hal penting dalam mengukur hasil (output) lembaga pendidikan dengan harapan pelanggan sesuai perkembangan zaman (Faizin \& Sholehati, 2019); (Dhafier, 2019).

Berdasarkan studi pendahuluan yang peneliti lakukan di SMK Negeri 4 Banjarmasin ditemukan bahwa sistem pelayanan yang diberikan ketika awal izin penelitian sampai tahapan penelitian sangatlah prosedural dan cepat, sehingga peneliti merasa dimudahkan dalam segala urusannya. Selain itu dari 
segi sarana prasarana sekolah, peneliti melihat sudah sangat bagus dan bahkan menurut peneliti sudah melebihi standar sekolah pada umumnya. Kemudian, prestasi-prestasi yang ditorehkan juga sangat banyak, hal ini bisa peneliti lihat dari banyaknya piala dan penghargaan yang terpajang di sekolah maupun berdasarkan yang peneliti lihat di berita/pengumuman di media sosial dan website yang dimiliki dan dikelola oleh SMK Negeri 4 Banjarmasin. Berdasarkan informasi yang peneliti dapatkan bahwa sekolah tersebut merupakan salah satu sekolah SMK terfavorit di Banjarmasin yang sudah menerapkan standar ISO 9001: 2015 dan merupakan SMK yang masuk dalam kategori SMK Program Keungggulan (SMK PK). Maka, berdasarkan studi pendahuluan tersebut, melalui penelitian ini peneliti ingin mengetahui lebih dalam dan mendeskripsikan mengenai upaya peningkatan mutu yang dilakukan oleh SMK Negeri 4 Banjarmasin dengan penerapan sistem manajemen mutu ISO 9001: 2015 dan dampaknya terhadap budaya dan sistem manajemen sekolah. Penelitian ini diharapkan memiliki kegunaan dalam kajian teoritis dan tataran praxis dalam proses dan manfaat dari penerapan ISO 9001: 2015 sebagai langkah untuk peningkatan mutu pendidikan demi tercapainya tujuan Pendidikan Nasional.

\section{METODE PENELITIAN}

Penelitian yang akan dilakukan oleh peneliti adalah penelitian lapangan (field research) yaitu mengumpulkan data yang langsung dilakukan di lokasi penelitian. Adapun pendekatan yang digunakan adalah pendekatan kualitatif deskriptif. Lokasi penelitan adalah SMK Negeri 4 Banjarmasin. Alasan penentuan lokasi tersebut dikarenakan sekolah tersebut sejak 2008 hingga sekarang masih menggunakan ISO 9001 sebagai sistem manajemen mutu sekolahnya. Waktu penelitian dilakukan pada bulan Oktober-November 2021.

Subjek yang diteliti dalam penelitian ini hanya fokus kepada koordinator atau penangungjawab mutu sekolah yaitu Wakil Kepaka Sekolah Bidang Manajemen Mutu (WMM) SMK Negeri 4 Banjarmasin. Subjek penelitian tersebut yang akan menjadi informan dalam penelitian ini sehingga didapatkan informasi mengenai tahapan penerapan sistem manajemen mutu ISO 9001: 2015 di SMK Negeri 4 Banjarmasin.

Untuk memperoleh data yang valid dan sesuai dengan permasalahan yang diteliti, peneliti akan menggunakan beberapa metode pengumpulan data, yaitu: observasi, wawancara, dan dokumentasi. Observasi dilakukan untuk mengamati fenomena sistem yang diterapkan di SMK Negeri 4 Banjarmasin khususnya dalam hal pelayanan dan juga komunikasi dan informasi kepada pelanggan sekolah. Kemudian wawancara dilakukan untuk memperoleh 
informasi mengenai tahapan penerapan sistem manajemen mutu ISO 9001: 2015 dan didukung dengan tahap dokumentasi untuk mendapatkan berkasberkas atau arsip yang dimiliki oleh WMM yang berkaitan dengan ISO 9001:2015. Setelah data berupa transkrip hasil wawancara dan observasi, dan dokumentasi dianggap lengkap dan sempurna, peneliti melakukan triangulasi data. Adapun analisis data yang peneliti gunakan adalah Model Miles and Huberman yakni kondensasi, penyajian data dan kesimpulan/verifikasi (Sugiyono, 2018).

\section{HASIL DAN PEMBAHASAN}

Tahapan Penerapan Sistem Manajemen Mutu ISO 9001: 2015 di SMK Negeri 4 Banjarmasin

Era globalisasi memberikan pengaruh yang besar terhadap persaingan di dunia kerja baik di level nasional hingga internasional. Hal tersebut kemudian secara tidak langsung mengharuskan lembaga-lembaga pendidikan kejuruan yang outputnya adalah siap kerja untuk menyelenggarakan pendidikan yang bermutu dan tersertifikasi secara internasional jika ingin bertahan dan siap menghadapi besarnya arus globalisasi. Dengan menerapkan sistem manajemen mutu ISO, lembaga pendidikan pada umumnya dapat menciptakan sinergi dengan akreditasi sekolah serta dapat meningkatkan citra positif terhadap pelanggan sekolah (Isnaini et al., 2020). Faktor yang dominan dalam peningkatan mutu di lembaga pendidikan adalah adanya dukungan dari pemerintah, masyarakat dan seluruh stakeholders yang ada dilembaga pendidikan tersebut. Analisis terhadap peluang dan ancaman harus selalu menjadi prioritas dalam hal peningkatan mutu lembaga (Ulum, 2017).

Awalnya sebelum penerapan mutu ISO ada istilah Rintisan Sekolah Bertaraf Internasional (RSBI), namun sekarang sudah ada perubahan kebijakan untuk menghapuskan RSBI. Oleh sebab perubahan kebijakan tersebut kemudian mendorong sekolah merasa perlu untuk menggunakan sistem penjaminan mutu yang terstandarisasi internasional yakni ISO 9001. Kepemimpinan atau kepala sekolah sangat berperan penting dalam hal ini, awal penerapan sistem manajemen mutu ISO 9001 di SMK Negeri 4 Banjarmasin adalah karena adanya kesadaran dan keinginan kepala sekolah untuk menjamin mutu di sekolah tersebut. Selain itu, juga dikarenakan adanya sebuah keharusan serta kesadaran dari pihak sekolah dalam mewujudkan tujuan Pendidikan Nasional. Analisis SWOT dilakukan di sekolah tersebut untuk melihat apa saja kekuatan yang dimiliki oleh sekolah dan memaksimalkan kekuatan tersebut untuk mengatasi beberapa kelemahan yang dimiliki, dan juga menganalisis berbagai peluang untuk menghadapi 
berbagai tantangan yang sedang atau nantinya akan dihadapi oleh pihak sekolah seperti dalam persaingan kesempatan dalam lapangan pekerjaan.

Sekolah Menengah Kejuruan (SMK) merupakan salah satu lembaga pendidikan yang berperan penting dalam menghasilkan output peserta didik yang siap kerja sehingga sangat perlu untuk menyelenggarakan sistem penjaminan mutu salah satunya berupa penerapan International Standar Organization (ISO) 9001. Sertifikasi ISO dilembaga pendidikan diperoleh setelah lembaga pendidikan berhasil melalui tahapan-tahapan yang sudah ditetapkan oleh lembaga penyelenggara sertifikasi (Iman, 2021). Mengikuti pelatihan mengenai sistem manajemen mutu ISO 9001: 2015 merupakan langkah penting yang harus ditempuh oleh tim mutu sekolah (Hunusalela et al., 2021). Semua tahapan berupa proses formal, prosedur serta pelatihan personil harus sudah dilakukan oleh lembaga pendidikan untuk bisa memiliki kesempatan menerapkan sistem manajemen mutu ISO 9001: 2015. Hal yang paling mendasar dalam penerapan ISO 9001: 2015 adalah adanya keharusan dalam hal analisis risiko dan aktivitas manajemen (risk management) (Leontyuk et al., 2019).

SMK Negeri 4 Banjarmasin yang beralamat di Jalan Brigjend H. Hasan Basry No. 7, Banjarmasin, Kalimantan Selatan telah berdiri sejak 1956. SMK Negeri 4 Banjarmasin sudah menerapkan International Standar Organization (ISO) 9001 sejak 2008 hingga sekarang dari mulai ISO 9001: 2008 hingga saat ini ISO 9001: 2015. Jadi, sejak kepemimpinan Bapak Susilo hingga kepemimpinan Bapak Syafruddin Noor sekarang, sudah memasuki periode kepemimpinan yang keempat dalam menerapkan dan melanjutkan ISO 9001 sebagai standar mutu sekolah. Sistem manajemen mutu ISO 9001 itu kini sudah menjadi tradisi di SMK Negeri 4 Banjarmasin sehingga seluruh anggota sekolah harus mengikuti sistem tersebut meskipun sebenarnya penerapan sistem ini tidak diwajibkan, tapi penerapan tersebut adalah karena keinginan atas dasar kesadaran dari pihak sekolah. Adapun Visi dari sekolah tersebut adalah Menjadi SMK yang unggul, kompeten, berkarakter, peduli lingkungan dan berdaya saing global. Penerapan sistem ISO 9001:2015 di SMK Negeri 4 Banjarmasin adalah untuk menuju ketercapaian visi lembaga yang berdaya saing global dan tentunya sebagai sebuah sistem penjaminan mutu sekolah.

Sejarah awalnya ISO menerbitkan seri ISO 9000 pada tahun 1987. Kemudian seri ISO 9000 yang mencakup tiga standar ISO 9001, 9002, 9003 pada versi ketiga digabungkan mejadi ISO 9001: 2000, hingga sekarang ISO terbaru adalah ISO 9001: 2015. ISO versi 2015 berfokus pada identifikasi resiko dan pengendalian resiko. Selain itu menuntut manajemen puncak untuk dapat mengambil peran yang lebih aktif dalam menyelaraskan kebijakan mutu 
dengan kebutuhan pelanggan. Untuk mendapatkan sertifikasi ISO 9001 lembaga pendidikan perlu mengeluarkan dana dalam tiga komponen yakni dalam proses membangun sistem mutu, sewa konsultan dan membayar biaya audit sertifikasi, total biaya tergantung masing-masing lembaga penyelenggara dan yang menyelenggarakan (Manders, 2015).

Hal yang paling penting sebelum mengimplementasikan ISO 9001: 2015 adalah terlebih dahulu lembaga pendidikan sudah harus melaksanakan standarisasi nasional yang terdapat pada 8 standar nasional pendidikan (SNP) sesuai Peraturan Pemerintah. Di era revolusi industri 4.0 sistem penjaminan mutu ISO dapat digunakan sebagai strategi eskternal untuk menganalisis kebutuhan pelanggan sehingga kepuasan pelanggan dapat terpenuhi dengan prinsip utama melakukan perbaikan secara berkelanjutan dan fokus pada kepuasan pelanggan (Abidin \& Haq, 2021). Dalam hal kepuasan pelanggan, lembaga pendidikan sangat perlu untuk mengukur tingkat kepuasannya bisa melalui angket manual maupun online (Dewi et al., 2020). Harus terdapat integrasi-interkoneksi antara ISO 9001: 2015 dengan standar akreditasi nasional yang dilaksanakan oleh BAN-S/M, selain memenuhi standarisasi juga sebagai peningkatan mutu yang berkelanjutan dalam menghadapi tuntutan mutu pendidikan yang semakin berkembang (Antaresti, 2017).

Dalam mengejar mutu sekolah, khususnya dalam penerapan ISO 9001 di SMK Negeri 4 Banjarmasin tentu seluruh stakeholders dituntut untuk mengikuti peraturan sistem yang berlaku seperti administrasi atau dokumendokumen harus lengkap, segala aktifitas ada standar prosedurnya, keharusan pelaksanaan auditing baik di internal hingga eksternal, dan lain sebagainya. Akan tetapi, perlu kesadaran yang tinggi dari seluruh stakeholders akan pentingnya mutu dan juga merupakan sebuah keharusan sebagai pendidik dan tenaga kependidikan bekerja dengan kualitas terbaik. Penerapan ISO ini bukan merupakan kewajiban dari pemerintah untuk setiap sekolah, sehingga tentu ada pro dan kontra dari pihak sekolah khususnya akan hal tersebut, namun peran pemimpin yakni kepala sekolah harus betul-betul tegas kepada seluruh anggota bahwa keinginan untuk penerapan ISO adalah untuk kepentingan bersama khususnya untuk kepentingan sekolah yang bermutu. Terdapat 7 jurusan yang ada di SMK Negeri 4 Banjarmasin yakni: Tata Boga, Tata Busana, Tata Kecantikan, Rekayasa Perangkat Luna, Usaha Perjalanan Wisata, Akomodasi Perhotelan dan Seni Musik Populer, adapun akreditasi 6 jurusan di SMK Negeri 4 Banjarmasin dari Badan Akreditasi Nasional adalah AB dan hanya 1 jurusan Rekayasa Perangkat Lunak yang akreditasinya A dikarenakan ada beberapa guru pengajar di jurusan tersebut yang latar belakang pendidikannya belum sesuai dengan standar seharusnya. 
Kepala sekolah merupakan Top Management dalam penerapan ISO dan wakil kepala sekolah bidang manajemen mutu merupakan koordinator yang menangani langsung kegiatan mutu dilapangan mulai dari pembuatan jadwal, prosedur dan pengumpulan sasaran mutu dari masing-masing unit. Sasaran mutu itulah yang kemudian harus dipertanggungjawabkan ketercapaiannya $100 \%$ atau apabila terdapat kendala ketika menjalankannya sehingga sasaran mutu tidak tercapai itupun juga harus dipertanggungjawabkan. Setelah sasaran mutu itu tercapai akan ada rapat tinjauan manajemen, kemudian sasaran mutu selanjutnya yakni pelaksanaan audit internal seperti layaknya pelaksanaan audit eksternal. Kemudian, dalam pengukuran kepuasan pelanggan, wakil manajemen mutu juga melakukan survey kepuasaan pelanggan secara online (sejak pandemi covid-19) kepada pihak internal yakni siswa sebagai evaluasi bersama untuk melakukan peningkatan kinerja dan perbaikan mutu sekolah.

Mengenai standar operasional prosedur mutu yang diterapkan di SMK Negeri 4 Banjarmasin terdiri dari prosedur inti, pendukung dan peningkatan, sebagaimana tabel 1.

Tabel 1. Standar Prosedur Mutu

\begin{tabular}{cll}
\hline Prosedur & \multicolumn{1}{c}{ Tahapan } \\
\hline 1nti & 1. Prosedur Penerimaan Peserta Didik Baru \\
& 2. Prosedur Pembagian Tugas dan Jadwal Pembelajaran \\
3. & Prosedur Penyusunan Persiapan Pembelajaran \\
4. Prosedur Pembelajaran \\
5. Prosedur Supervisi Pembelajaran \\
6. Prosedur Evaluasi Pembelajaran \\
7. Prosedur Administrasi \& Pelaporan Hasil Pembelajaran \\
8. Prosedur Penegakan Disiplin Siswa \\
9. & Prosedur Praktik Kerja Lapangan (PKL) \\
10. & Prosedur Pemasaran Lulusan \\
11. & Prosedur Penelusuran Lulusan \\
12. & Prosedur Pengelolaan Sarana Prasarana \\
13. & Prosedur Bimbingan Konseling \\
14. & Prosedur Pengembalian Siswa \\
15. & Prosedur Penyusunan Program Sekolah \\
16. & Prosedur Peningkatan Kompetensi Personil \\
\hline 1. & Prosedur Promosi Sekolah \\
2. & Prosedur Kerjasama Antar Lembaga \\
3. & Prosedur Pengelolaan Unit Produksi \\
4. & Prosedur Pembinaan Lomba Keterampilan Siswa \\
5. & Prosedur Pelayanan Administrasi \\
6. & Prosedur Pengelolaan Perpustakaan \\
7. & Prosedur Pelaksanaan Kegiatan Ekstrakurikuler \\
8. & Prosedur Pengelolaan OSIS \\
9. & Prosedur Pengelolaan Lingkungan Hidup \\
\hline
\end{tabular}




\begin{tabular}{ll}
\hline & \\
\hline 10. Prosedur Kesehatan dan Keselamatan Kerja \\
11. Prosedur Pengelolaan dan Piket Harian \\
12. Prosedur Evaluasi Rekanan \\
\hline
\end{tabular}

Sumber: Data Diolah Penulis 2021

Prosedur bisa saja berubah menyesuaikan dengan kondisi dilapangan, maka ketika terdapat revisi dan perubahan akan di sosialisasikan dalam rapat tinjauan manajemen. Semua prosedur yang sudah dibuat oleh pihak sekolah harus betul-betul dijalankan dan dilengkapi, dikarenakan jika terdapat temuan mayor yakni yang berhubungan dengan kegiatan prosedur inti akan berakibat fatal yang akan merusak tatanan kerja dan mutu sekolah. Maka, jika ditemukan temuan mayor harus dibereskan dalam 20 hari kerja, dan berkas perbaikan yang sudah dibuat dikirimkan kembali kepihak auditor untuk dilakukan close temuan, jika tidak diberbaiki maka kemungkinan sertifikat akan dicabut oleh pihak yang memberikan sertifikat yakni PT. URS Service Indonesia karena masalahnya belum close.

Adapun berikut secara lebih ringkas mengenai tahapan yang dilaksanakan oleh SMK Negeri 4 Banjarmasin dalam menerapkan sistem manajemen mutu dari awal menggunakan ISO 9001: 2008 hingga saat ini menggunakan ISO 9001: 2015.

\section{Pelatihan}

Top management SMK Negeri 4 Banjarmasin mendelegasikan beberapa orang yakni para wakil kepala sekolah untuk mengikuti pelatihan tentang sistem manajemen mutu ISO 9001: 2008 dengan dibimbing oleh Konsultan dari Medan selama satu pekan, Konsultan tersebutllah yang merupakan pembimbing sekolah untuk menuju penerapan sistem manajemen mutu ISO 9001. Beberapa orang utusan dari Kepala Sekolah tersebutlah yang kemudian menjadi tim pengembang mutu di SMK Negeri 4 Banjarmasin dalam penerapan ISO 9001 dengan bimbingan Konsultan.

2. Pembuatan Dokumen dan Pelaksanaan

Setelah selesai mengikuti pelatihan, tim pengembang mutu sekolah kemudian kembali ke sekolah dan secara bersama-sama menyiapkan dan membuat dokumen mutu melalui bimbingan Konsultan dari Medan. Setelah selesai menyiapkan dokumen, pihak sekolah kemudian menerapkan sistem manajemen mutu sesuai dengan dokumen dan prosedur yang telah dibuat. 
Faktor sukses dalam penerapan sistem ISO di SMK Negeri 4 Banjarmasin adalah karena tingginya solidaritas dan profesionalisem tim manajemen sekolah. Setelah melaksanakan setiap prosedur yang dibuat, selanjutnya pihak sekolah mengadakan rapat untuk persiapan audit internal.

3. Audit internal

Dalam pelaksanaan audit internal, wakil kepala sekolah bidang manajemen mutu membentuk tim auditor yang terdiri dari 7 orang yakni wakil kepala bidang manajemen mutu kemudian wakil kepala bidang kurikulum, wakil kepala bidang sarana dan prasarana, wakil kepala bidang humas, wakil kepala bidang kesiwaan, wakil kepala bina program dan satu orang diluar wakil kepala sekolah namun sudah memiliki sertifikasi pelatihan ISO 9001 dari PT. URS Service Indonesia. Setelah dipilih dan dibentuk tim auditor kemudian kepala sekolah memberikan Surat Keputusan (SK) kepada tim tersebut untuk melaksanakan tugas-tugasnya. Setelah terbitnya Surat Keputusan maka masing-masing auditor akan melaksanakan audit internal minimal kepada dua unit misalkan wakil kepala bidang manajemen mutu kepada unit bimbingan konseling dan perpustakaan, kemudian humas kepada sarana dan prasarana, wakil kepala bidang kurikulum kepada wali kelas dan seterusnya sudah diatur dalam jadwal yang sudah disepakati bersama.

Wakil kepala sekolah bidang manajemen mutu selaku koordinator mutu memiliki standar operasional prosedur dalam pelaksanaan audit internal yang meliptui tujuan, ruang lingkup, rincian prosedur berupa perencanaan, pelaksanaan dan tindak lanjut serta lampiran program auditing. Adapun audit internal yang akan dilaksanakan oleh pihak SMK Negeri 4 Banjarmasin adalah di bulan Januari 2022 sebelum adanya pelaksanaan audit internal pada bulan April 2022, dilaksanakan bisa 6-7 hari.

4. Audit Eksternal

Setelah melaksanakan audit internal tahap selanjutnya adalah audit eksternal. Adapun pihak yang melakukan audit eksternal di SMK Negeri 4 Banjarmasin adalah PT. URS Service Indonesia cabang Balikpapan, pihak PT. URS kemudian menugaskan auditornya untuk melaksanakan audit terhadap pelaksanaan kesesuaian dokumen mutu sekolah dengan proses pelaksanaannya. Biaya awal yang harus disetorkan untuk pelaksanaan monitoring adalah \pm 15.000.000,-. Pelaksanaan audit eksternal dilaksanakan 1 tahun sekali, namun pihak sekolah bisa mengajukan pengunduran waktu audit eksternal kepada pihak auditor misalkan karena beberapa alasan, seperti: di awal tahun 2021 Provinsi Kalimantan sedang 
mengalami bencana banjir selama \pm 3 bulan sehingga sekolah tidak bisa beroperasi, sehingga audit yang harusnya dilaksanakan bulan Februari 2021 diganti menjadi bulan April 2021. Audit eksternal dilaksanakan 2-3 hari bisa dengan offline dan juga online (di masa pandemi covid-19).

5. Sertifikasi

Jika dalam proses audit eksternal tidak ditemukan temuan lapangan maka sertifikat ISO 9001: 2015 bisa segera diterbitkan oleh pihak PT. URS Service Indonesia. Akan tetapi jika didapati temuan, maka pihak auditor memberikan waktu perbaikan selama 20 hari kerja untuk segera memberpaikinya sesuai dengan masukan yang diberikan. Adapun masa berlaku sertifikat ISO 9001: 2015 adalah 1 tahun.

\section{Dampak dari Penerapan Sistem Manajemen Mutu ISO 9001: 2015 di SMK Negeri 4 Banjarmasin}

Organisasi/Perusahaan/Lembaga yang menerapkan standar ISO 9001 secara berkelanjutan dari tahun ke tahun tentunya akan memberikan manfaat dan dampak yang luar biasa terhadap kinerja yang lebih baik (Aba et al., 2016). Dengan menerapkan standar ISO 9001: 2015, lembaga pendidikan juga akan memperoleh manfaat berupa kejelasan tugas, sarana benchmarking antar unit kerja melalui kegiatan audit internal, serta berbagai kebijakan dan prosedur operasi dapat terstandarisasi (Mardika, 2019). Penerapan ISO 9001 juga memberikan dampak terhadap metodologi hingga evaluasi pengajaran yang dilaksanakan dalam proses belajar mengajar sehingga hasil dari proses tersebut bisa lebih tinggi dari rata-rata capaian seharusnya (Fernández-Cruz et al., 2019).

Dengan adanya penerapan ISO 9001: 2015 di SMK Negeri 4 Banjarmasin sangat berdampak terhadap sistem kerja dan ketertiban dari segi administrasi tenaga pendidik dan kependidikan di sekolah menggunakan media seperti WhatsApp/Googleclasroom/Google Meet yang juga dilengkapi dengan dokumen fisiknya. Dengan penerapan ISO juga dampaknya adalah kita dituntut untuk menerapkan pelayanan terbaik kepada pelanggan, sebagai contoh dalam pelayanan Tata Usaha di SMK Negeri 4 Banjarmasin membuat sasaran mutu yakni: setiap urusan selesai satu hari. Kemudian, dari keuangan juga sudah menggunakan sistem aplikasi keuangan yang lengkap. Sehingga apa yang dilaksanakan sudah tersistem dan otomatis yang sangat memudahkan dalam pekerjaan penginputan dana masuk dan keluar. Ketika adanya audit keuangan dari BPK atau inspektorat mengenai keuangan, pihak sekolah sudah siap dengan data-data tersebut. Dengan sistem mutu yang dibangun seperti itu akhirnya mobilitas masing-masing unit sudah 
mengetahui apa yang harus dikerjakan, yang nantinya semuanya akan dipertanggungjawabkan lewat auditing internal dan eksternal. Adapun audit yang nantinya dilakukan adalah keterlaksanaan atau tidaknya target dari sasaran mutu tersebut.

Hal tersebut di atas dilaksanakan karena lembaga yang menerapkan sistem manajemen mutu ISO 9001 harus memiliki jejak rekam pengetahuan untuk keberlanjutan pengembangan mutu ISO 9001 berupa catatan berbagai aktifitas yang berkaitan dengan peningkatan mutu yang terhimpun dalam dokumen-dokumen yang bisa dipelajari (Demir et al., 2021). Dalam pemetaan mutu, sekolah dapat melakukan sistem penjaminan mutu internal mulai dari evaluasi diri sekolah (EDS) sesuai standar nasional pendidikan (SNP). Apabila terdapat kekurangan dalam hal standar mutu maka sekolah berperan untuk melakukan perbaikan dan pemenuhan mutu secara berkelanjutan (Zahrok, 2020). Motivasi yang besar dari kepala sekolah untuk para guru dalam peningkatan kompetensinya tentu sangat diperlukan, usaha yang dapat dilakukan yakni melalui pelatihan-pelatihan dalam hal peningkatan keterampilan mengajar dan pemahaman akan pentingnya manajemen mutu (Fauzi et al., 2020).

Terdapat perubahan secara signifikan dari ISO 9001: 2008 dengan 9001: 2015 yakni terletak pada istilah yang digunakan di ISO 9001:2008 adalah Preventive Action diganti dengan Risk Management di ISO 9001: 2015, istilah tersebut yang sebelumnya merupakan tindakan pencegahan diganti ruang lingkup cakupannya menjadi lebih luas yakni manajemen resiko (Nugroho, 2017). Prosedur yang memuat unsur risk management (manajemen resiko) merupakan persyaratan penting dalam penerapan sistem manajemen mutu ISO 9001:2015 dilembaga pendidikan (Kartikasari, 2018). Melalui penerapan ISO 9001: 2015 sekolah kemudian dituntut untuk menganalisis dan membuat risk management (manajemen risiko) sebagaimana yang dilakukan oleh unit manajemen di SMK Negeri 4 Banjarmasin terdiri dari bidang kurikulum, sarana prasarana, kesiswaan humas, wakil manajemen mutu, bina program dan ketenagaan, perpustakaan, tata usaha, dan bimbingan konseling, bisa dilihat di tabel. 2 .

Tabel. 2. Risk Management (Manajemen Risiko)

\begin{tabular}{|c|c|c|c|c|}
\hline Bidang & Kondisi saat ini & Dampaknya & $\begin{array}{l}\text { Kondisi yang } \\
\text { diharapkan }\end{array}$ & $\begin{array}{c}\text { Program } \\
\text { Kedepannya }\end{array}$ \\
\hline $\begin{array}{l}\text { Kurikul } \\
\text { um }\end{array}$ & $\begin{array}{l}\text { 1. Pelajaran teori } \\
\text { dilaksanakan } \\
\text { jarak } \\
\text { jauh/online }\end{array}$ & $\begin{array}{l}\text { 1. KBM tidak } \\
\text { maksimal } \\
\text { 2. Target } \\
\text { kurikulum }\end{array}$ & $\begin{array}{ll}\text { 1. } & \text { KBM tetap } \\
\text { maksimal } \\
\text { 2. Kompetensi } \\
\text { Dasar (KD) mata }\end{array}$ & $\begin{array}{l}\text { 1. Workshop } \\
\text { membuat } \\
\text { kurikulum } \\
\text { mandiri }\end{array}$ \\
\hline
\end{tabular}


(Penerapan Sistem Manajemen Mutu ISO 9001: 2015 Di SMK Negeri 4 Banjarmasin)

\begin{tabular}{|c|c|c|c|c|}
\hline & $\begin{array}{l}\text { 2. Pembelajaran } \\
\text { praktik } \\
\text { dilaksanakan } \\
\text { secara tatap } \\
\text { muka secara } \\
\text { terbatas }\end{array}$ & $\begin{array}{l}\text { tidak bisa } \\
\text { tercapai } \\
100 \% \\
\text { 3. Pembelajara } \\
\text { n daring } \\
\text { 4. KD } \\
\text { keterampila } \\
\text { n tidak } \\
\text { maksimal }\end{array}$ & $\begin{array}{l}\text { pelajaran } \\
\text { muatan } \\
\text { peminatan } \\
\text { kejuruan siswa } \\
\text { tetap bisa } \\
\text { tercapai }\end{array}$ & $\begin{array}{l}\text { 2. In House } \\
\text { Training } \\
\text { 3. PTM Terbatas }\end{array}$ \\
\hline $\begin{array}{l}\text { Sarana } \\
\text { Prasara } \\
\text { na }\end{array}$ & $\begin{array}{l}\text { 1. Belum ada } \\
\text { tenaga teknisi } \\
\text { peralatan } \\
\text { praktik } \\
\text { 2. Belum } \\
\text { menggunakan } \\
\text { aplikasi untuk } \\
\text { stok alat dan } \\
\text { bahan habis } \\
\text { pakai }\end{array}$ & $\begin{array}{l}\text { 1. Untuk } \\
\text { perawatan } \\
\text { dan } \\
\text { perbaikan } \\
\text { peralatan } \\
\text { praktik } \\
\text { tidak dapat } \\
\text { segera } \\
\text { diperbaiki } \\
\text { 2. Penggunaan } \\
\text { alat dan } \\
\text { bahan pakai } \\
\text { tidak } \\
\text { terdokumen } \\
\text { tasi dengan } \\
\text { baik }\end{array}$ & $\begin{array}{l}\text { 1. Idealnya harus } \\
\text { ada tenaga } \\
\text { teknis sesuai } \\
\text { dengan } \\
\text { peralatan } \\
\text { praktik tiap } \\
\text { jurusan } \\
\text { 2. Ada aplikasi stok } \\
\text { barang sehingga } \\
\text { penggunaan alat } \\
\text { dan bahan habis } \\
\text { pakai dapat } \\
\text { didokumentasika } \\
\text { n dengan baik }\end{array}$ & $\begin{array}{l}\text { 1. } \text { Mengajukan } \\
\text { permohonan } \\
\text { kepada Dinas } \\
\text { Pendidikan } \\
\text { Provinsi } \\
\text { untuk } \\
\text { penambahan } \\
\text { tenaga teknisi } \\
\text { 2. Mengajukan } \\
\text { anggaran } \\
\text { untuk } \\
\text { pembuatan } \\
\text { aplikasi stok } \\
\text { barang }\end{array}$ \\
\hline $\begin{array}{l}\text { Kesisw } \\
\text { aan }\end{array}$ & $\begin{array}{l}\text { 1. Pelaksanaan } \\
\text { kegiatan } \\
\text { esktrakurikule } \\
\text { r terkendala } \\
\text { dikarenakan } \\
\text { pandemi } \\
\text { covid-19 } \\
\text { selama } 1 \\
\text { tahun lebih } \\
\text { 2. Persentasi } \\
\text { kehadiran } \\
\text { siswa/absensi } \\
\text { harian tidak } \\
\text { dapat } \\
\text { dilaksanakan } \\
\text { secara } \\
\text { maksimal }\end{array}$ & 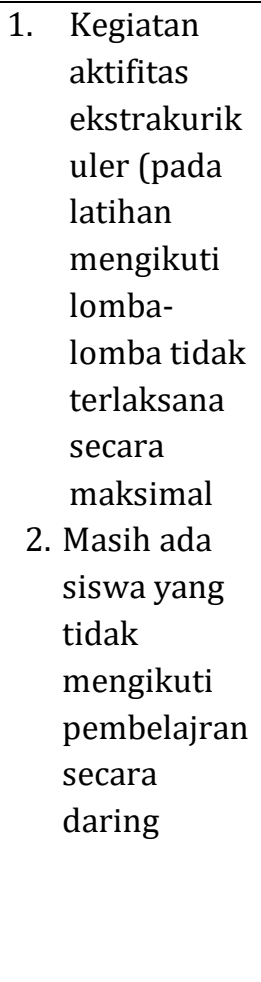 & 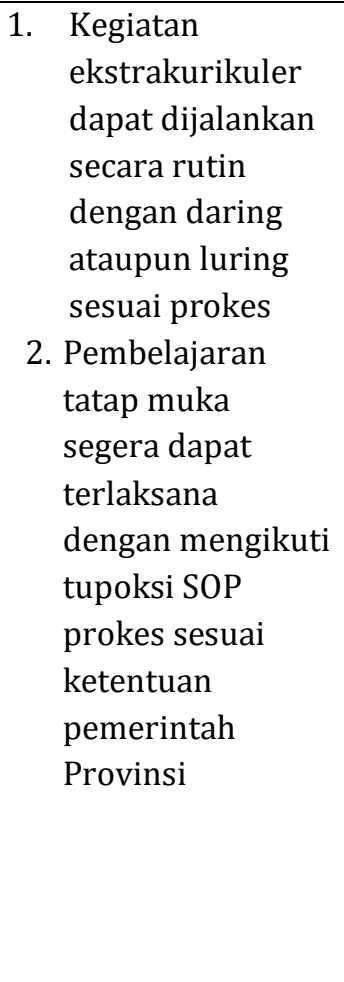 & $\begin{array}{l}\text { 1. Akan } \\
\text { mengkaji } \\
\text { ulang } \\
\text { program } \\
\text { ekstrakurikul } \\
\text { er agar dapat } \\
\text { terlaksana } \\
\text { secara daring } \\
\text { dan luring } \\
\text { sesuai prokes } \\
\text { 2. Ketertiban } \\
\text { dalam } \\
\text { mengikuti } \\
\text { pembelajaran } \\
\text { dapat } \\
\text { dilaksanakan } \\
\text { dengan } \\
\text { membuat } \\
\text { absensi yang } \\
\text { terlink ke } \\
\text { Kurikulum/Ke }\end{array}$ \\
\hline
\end{tabular}




\begin{tabular}{|c|c|c|c|c|}
\hline & & & & $\begin{array}{l}\text { siswaan dan } \\
\text { tata usaha }\end{array}$ \\
\hline \multirow[t]{2}{*}{ Humas } & $\begin{array}{l}\text { Pelaksanaan PKL } \\
\text { dalam masa } \\
\text { pandemi covid } 19 \\
\text { tetap } \\
\text { dilaksanakan } \\
\text { sesuai prosedur } \\
\text { kesehatan }\end{array}$ & $\begin{array}{l}\text { 1. Ada } \\
\text { beberapa } \\
\text { DU/DI yang } \\
\text { tidak dapat } \\
\text { menerima } \\
\text { siswa PKL } \\
\text { 2. Jumlah } \\
\text { DU/DI yang } \\
\text { terbatas } \\
\text { 3. Ada } \\
\text { beberapa } \\
\text { siswa yang } \\
\text { terdampak } \\
\text { covid } 19\end{array}$ & $\begin{array}{l}\text { 1. Kegiatan PKL } \\
\text { dapat } \\
\text { dilaksanakan } \pm 6 \\
\text { bulan } \\
\text { 2. } \text { DU/DI } \\
\text { menerapkan } \\
\text { prokes Covid } 19 \\
\text { yang ketat untuk } \\
\text { menghindari } \\
\text { penyebaran Covid } \\
19\end{array}$ & $\begin{array}{l}\text { 1. Kondisi PKL } \\
\text { dapat berjalan } \\
\text { dengan } \\
\text { normal } \\
\text { 2. Siswa yang } \\
\text { akan } \\
\text { melaksanakan } \\
\text { PKL diberikan } \\
\text { pembekalan } \\
\text { yang } \\
\text { maksimal } \\
\text { 3. Membuat } \\
\text { program } \\
\text { kegiatan PKL + } \\
6 \text { bulan sesuai } \\
\text { dengan } \\
\text { harapan } \\
\text { DU/DI }\end{array}$ \\
\hline & $\begin{array}{l}\text { 1. Pelaksanaan } \\
\text { PKL masa } \\
\text { pandemi } \\
\text { Covid } 19 \\
\text { tahun ini } \\
\text { dilaksanakan } \\
\text { dalam } 2 \\
\text { periode, yaitu } \\
\text { pada: } \\
\text { 1) Semester } 4 \\
\text { kelas XI } \\
\text { untuk Tata } \\
\text { busana, } \\
\text { tata } \\
\text { kecantikan, } \\
\text { RPL, UPW } \\
\text { dan seni } \\
\text { musik } \\
\text { 2) Semester } 6 \\
\text { kelas XII } \\
\text { untuk tata } \\
\text { boga dan } \\
\text { perhotelan }\end{array}$ & $\begin{array}{l}\text { Bagi } \\
\text { siswa/siswi } \\
\text { yang } \\
\text { melaksanakan } \\
\text { PKL di kelas XI } \\
\text { masih } \\
\text { mendapatkan } \\
\text { kompetensi } \\
\text { yang } \\
\text { maksimal, } \\
\text { untuk kelas X } \\
\text { selama masa } \\
\text { pandemi } \\
\text { belum } \\
\text { terlaksana }\end{array}$ & $\begin{array}{l}\text { Kegiatan PKL dapat } \\
\text { dilaksanakan sesuai } \\
\text { dengan jadwal yang } \\
\text { sudah dibuat dan } \\
\text { mendapatkan } \\
\text { pembekalan materi } \\
\text { kejuruan secara } \\
\text { maksimal untuk } \\
\text { mempersiaokan } \\
\text { siswa dengan baik } \\
\text { pada saat memasuki } \\
\text { DU/DI }\end{array}$ & $\begin{array}{l}\text { Kegiatan PKL } \\
\text { dilaksanakan } \\
\text { secara serempak } \\
\text { pada semester } 5 \\
\text { pada saat siswa } \\
\text { sudah naik kelas } \\
\text { XII sehingga siswa } \\
\text { sudah } \\
\text { mendapatkan } \\
\text { bekal \& } \\
\text { kompetensi yang } \\
\text { cukup saat } \\
\text { memasuki DU/DI }\end{array}$ \\
\hline $\begin{array}{l}\text { Wakil } \\
\text { Manaje } \\
\text { men } \\
\text { Mutu }\end{array}$ & $\begin{array}{l}\text { 1. Kotak saran } \\
\text { yang } \\
\text { disiapkan } \\
\text { kurang }\end{array}$ & $\begin{array}{l}\text { 1. Pihak } \\
\text { manajemen } \\
\text { tidak } \\
\text { banyak }\end{array}$ & $\begin{array}{l}\text { 1. Siswa dapat } \\
\text { menyampaikan } \\
\text { keluhannya } \\
\text { melalui: Kotak }\end{array}$ & $\begin{array}{l}\text { 1. Diberikan } \\
\text { himbauan } \\
\text { bagi siswa } \\
\text { agar dapat }\end{array}$ \\
\hline
\end{tabular}




\begin{tabular}{|c|c|c|c|c|}
\hline & $\begin{array}{l}\text { diminati siswa } \\
\text { untuk } \\
\text { 2. } \\
\text { Internal Audit } \\
\text { memerlukan } \\
\text { waktu lama } \\
\text { karena } \\
\text { kesibukan } \\
\text { para auditor }\end{array}$ & $\begin{array}{l}\text { mengetahui } \\
\text { keluhan } \\
\text { pelanggan } \\
\text { 2. Laporan } \\
\text { internal } \\
\text { audit } \\
\text { terkendala } \\
\text { untuk } \\
\text { segera } \\
\text { diselesaikan }\end{array}$ & $\begin{array}{l}\text { saran, BK, Angket } \\
\text { siswa, Konsultasi } \\
\text { daring dan luring } \\
\text { 2. Internal audit } \\
\text { dilaksanakan } \\
\text { sesuai dengan } \\
\text { yang sudah } \\
\text { diprogramkan }\end{array}$ & $\begin{array}{l}\text { memberikan } \\
\text { saran dan } \\
\text { masukan } \\
\text { kepada pihak } \\
\text { manajemen } \\
\text { melalui } \\
\text { daring } \\
\text { 2. Diprogramkan } \\
\text { lebih awal } \\
\text { waktunya }\end{array}$ \\
\hline $\begin{array}{l}\text { Bina } \\
\text { Progra } \\
\text { m dan } \\
\text { Ketena } \\
\text { gaan }\end{array}$ & 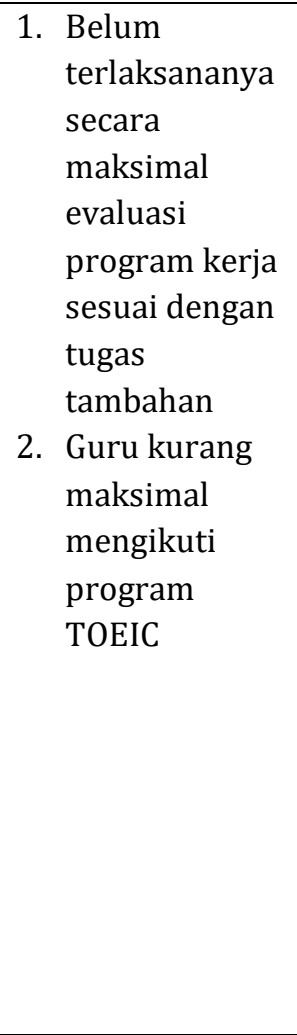 & $\begin{array}{l}\text { 1. Belum } \\
\text { maksimal } \\
\text { membuat } \\
\text { tindak } \\
\text { lanjut atau } \\
\text { revisi } \\
\text { proker } \\
\text { secara } \\
\text { berkala } \\
\text { 2. Tidak semua } \\
\text { guru } \\
\text { berkeingina } \\
\text { n mengikuti } \\
\text { test TOEIC }\end{array}$ & $\begin{array}{l}\text { 1. Semua tendik } \\
\text { dan } \\
\text { kependidikan } \\
\text { membuat buku } \\
\text { evaluasi program } \\
\text { sesuai dengan } \\
\text { tugas } \\
\text { tambahannya } \\
\text { 2. Semua tendik } \\
\text { bisa mengikuti } \\
\text { test TOEIC sesuai } \\
\text { program } \\
\text { sekolah/DSMK }\end{array}$ & $\begin{array}{l}\text { 1. Mengadakan } \\
\text { rapat } \\
\text { koordinasi } \\
\text { khusus } \\
\text { evaluasi } \\
\text { program kerja } \\
\text { secara } \\
\text { berkala } \\
\text { 2. Meningkatkan } \\
\text { program } \\
\text { diklat bagi } \\
\text { tendik dan } \\
\text { kependidikan } \\
\text { baik secara } \\
\text { mandiri } \\
\text { ataupun } \\
\text { kolektif } \\
\text { ataupun luring } \\
\text { berkaitan } \\
\text { dengan } \\
\text { penguasaan } \\
\text { bahasa asing }\end{array}$ \\
\hline $\begin{array}{l}\text { Perpust } \\
\text { akaan }\end{array}$ & $\begin{array}{l}\text { Sedikitnya } \\
\text { pengunjung } \\
\text { perpustakaan } \\
\text { selama pandemi } \\
\text { Covid } 19\end{array}$ & $\begin{array}{l}\text { Menurunnya } \\
\text { minat baca dan } \\
\text { kunjungan } \\
\text { pemustaka/sis } \\
\text { wa selama } \\
\text { pandemi }\end{array}$ & $\begin{array}{l}\text { Adanya peningkatan } \\
\text { kunjungan dan } \\
\text { minat baca } \\
\text { siswa/pengunjung }\end{array}$ & $\begin{array}{l}\text { Pembuatan } \\
\text { smart library/ } \\
\text { mobile library } \\
\text { dan pembelian } e \text { - } \\
\text { book untuk } \\
\text { menunjang } \\
\text { kembali minat } \\
\text { baca dan } \\
\text { kunjungan } \\
\text { perpustakaan }\end{array}$ \\
\hline $\begin{array}{l}\text { Tata } \\
\text { usaha }\end{array}$ & $\begin{array}{l}\text { Penyaluran dana } \\
\text { BOSDA tidak } \\
\text { sesuai jadwal atau } \\
\text { diawal tahun } \\
\text { anggaran }\end{array}$ & $\begin{array}{l}\text { Pelaksanaan } \\
\text { program kerja } \\
\text { sekolah } \\
\text { menyesuaikan } \\
\text { dengan dana } \\
\text { yang ada } \\
\end{array}$ & $\begin{array}{l}\text { Dana BOSDA } \\
\text { disalurkan di awal } \\
\text { tahun anggaran } \\
\text { sehingga program } \\
\text { kerja sekolah dapat } \\
\text { dilaksanakan sesuai }\end{array}$ & $\begin{array}{l}\text { Jadwal } \\
\text { pelaksanaan } \\
\text { program kerja } \\
\text { disesuaikan } \\
\text { dengan dana } \\
\text { yang diterima } \\
\end{array}$ \\
\hline
\end{tabular}




\begin{tabular}{|c|c|c|c|c|}
\hline & & & $\begin{array}{l}\text { dengan rencana } \\
\text { (RKAS) }\end{array}$ & \\
\hline $\begin{array}{l}\text { Bimbin } \\
\text { gan } \\
\text { konseli } \\
\text { ng }\end{array}$ & $\begin{array}{l}\text { 1. Pelaksanaan } \\
\text { layanan BK } \\
\text { melalui daring } \\
\text { 2. Bekerja sama } \\
\text { dengan wali } \\
\text { kelas dan } \\
\text { orang tua } \\
\text { siswa secara } \\
\text { daring } \\
\text { ataupun luring }\end{array}$ & $\begin{array}{l}\text { Harus } \\
\text { beradaptasi } \\
\text { dengan masa } \\
\text { pandemi } \\
\text { covid-19 }\end{array}$ & $\begin{array}{l}\text { Setiap } \\
\text { penanggungjawab } \\
\text { menjadi tupoksinya }\end{array}$ & $\begin{array}{l}\text { Akan } \\
\text { diprogramkan } \\
\text { dan } \\
\text { disosialisasikan } \\
\text { tupoksi } \\
\text { penanggungjawa } \\
\text { b masing-masing }\end{array}$ \\
\hline
\end{tabular}

Sumber: Dokumentasi SMK Negeri 4 Tahun 2021

Secara global, penerapan ISO 9001: 2015 di SMK Negeri 4 Banjarmasin memberikan dampak berupa pengalaman kerja pendidik dan tenaga kependidikan yang bekerja lebih baik dan tertata sesuai prosedur dan tercipta tim yang solid dan profesional. Selain itu juga terciptanya mindset akan satu visi dan satu misi, mereka sudah terpola untuk mencapai tujuan bersama dalam hal peningkatan mutu sekolah. Melalui prosedur mutu yang dijalankan kepuasan pelanggan adalah hal yang harus diutamakan baik pelanggan eksternal yakni siswa dan guru, juga kepuasan pelanggan eksternal selaku pengguna lulusan seperti Dunia Usaha/Dunia Industri (DUDI).

\section{KESIMPULAN}

Beberapa tahapan yang dilaksanakan oleh SMK Negeri 4 Banjarmasin dalam penerapan sistem manajemen mutu ISO 9001: 2015 adalah 1) mengikuti pelatihan dengan bimbingan konsultan, 2) penyiapan dokumen mutu dan pelaksanaan sistem manajemen mutu sesuai dokumen yang telah dibuat oleh pihak sekolah, 3) audit internal yang dikoordinir oleh Wakil Manejemen Mutu, 4) audit eksternal yang dilakukan oleh PT. URS Service Indonesia, dan 5) pemberian sertifikat ISO 9001: 2015/ Sertifikasi lembaga. Adapun yang menjadi poin penting dan menjadi acuan utama dalam penerapan sistem manajemen mutu ISO 9001: 2015 di SMK Negeri 4 Banjarmasin adalah prosedur mutu yang harus dijalankan yang terdiri dari prosedur inti, prosedur pendukung, dan prosedur peningkatan serta keharusan akan pembuatan risk management bagi masing-masing unit. Adapun dampak dari penerapan sistem manajemen mutu ISO 9001: 2015 di SMK Negeri 4 Banjarmasin adalah terciptanya sistem kerja yang lebih baik, tertata sesuai prosedur dan dapat menciptakan budaya kerja tim yang menjunjung tinggi solidaritas dan profesionalisme kerja. 


\section{DAFTAR PUSTAKA}

Aba, E. K., Badar, M. A., \& Hayden, M. A. (2016). Impact Of ISO 9001 Certification On Firms Financial Operating Performance. International Journal of Quality and Reliability Management, 33(1), 78-89. https://doi.org/10.1108/IJQRM-02-2014-0021

Abidin, Z., \& Haq, M. S. (2021). Sistem Manajemen Mutu ISO 9001:2015 Sebagai Strategi Peningkatan Kualitas Pendidikan Di Era 4.0. Jurnal Inspirasi Manajemen Pendidikan, 9(1), 445-459.

Alfiansyah, M., Assingkily, M. S., \& Prastowo, A. (2020). Kebijakan Internal Madrasah Dalam Meningkatkan Mutu Pendidikan Di MI Nurul Ummah Kotagede Yogyakarta. MAGISTRA: Media Pengembangan Ilmu Pendidikan Dasar Dan Keislaman, 11(1), 52-67. https://doi.org/10.31942/mgs.v11i1.3460

Antaresti. (2017). Integrasi ISO 9001:2015 dan Standar Akreditasi BAN-PT Untuk Meningkatkan Daya Saing Institusi Pendidikan Tinggi di Era Masyarakat Ekonomi ASEAN. Jurnal Ilmiah Ilmu Administrasi Dan Sekretari, 1(1), 1-10.

Demir, A., Budur, T., Omer, H. M., \& Heshmati, A. (2021). Links Between Knowledge Management And Organisational Sustainability: Does The ISO 9001 Certification Have An Effect? Knowledge Management Research and Practice, 1-14. https://doi.org/10.1080/14778238.2020.1860663

Dewi, Y. K., Juliejantiningsih, Y., \& Nurkolis. (2020). Implementasi ISO 9001:2015 Dalam Penjaminan Mutu SMP Negeri 2 Kabupaten Demak. Jurnal Manajemen Pendidikan (JMP), 9(1), 1-16. https://doi.org/10.26877/jmp.v9i1.6833

Dhafier, M. H. (2019). Analisis Kendala-Kendala dalam Penerapan SMM ISO 9001:2008 di Madrasah Aliyah Negeri 3 Palembang. Studia Manageria: Jurnal Manajemen Pendidikan Islam, 1(1), 69-82.

Fadli, M. (2017). Manajemen Peningkatan Mutu Pendidikan. Tadbir : Jurnal Studi Manajemen Pendidikan, 1(02), 215-240.

Faizin, \& Sholehati, W. (2019). Peningkatan Daya Saing Pendidikan Melalui Manajemen Mutu Iso 9001: 2008. MANAGERE: Indonesian Journal of Educational Management, 1(1), 30-50. https://doi.org/10.52627/ijeam.v1i1.7

Fauzi, H. N., Perawironegoro, D., \& Suyadi. (2020). Implementasi Manajemen Mutu Terpadu Sebagai Strategi Efektif Dalam Meningkatkan Kinerja Sekolah. Adaara: Jurnal Manajemen Pendidikan Islam, 10(2), 147-153.

Fernández-Cruz, Rodríguez-Mantilla, J. M., \& Fernández-Díaz, M. J. (2019). Assessing The Impact Of ISO: 9001 Implementation On School Teaching And Learning Processes. Quality Assurance in Education, 27(3), 285-303. https://doi.org/10.1108/QAE-09-2018-0103

Hunusalela, Z. F., Perdana, S., \& Tiara. (2021). Pelatihan ISO 9001: 2015 Kepada Lembaga Bimbingan Belajar Insan Cendikia Gemilang. JURNAL IKRAITH-ABDIMAS, 4(3), 205-210.

Iman, K. N. (2021). Implementasi Manajemen Mutu Berbasis Iso 9001 : 2015 Di 
SMK Ma 'Arif NU Bobotsari Kecamatan Bobotsari Kabupaten Purbalingga. IAIN Purwokerto.

Isnaini, S., Syukur, F., \& Khunaifi, A. (2020). Implikasi Penerapan Sistem Manajemen Mutu ISO 9001:2015 di Madrasah (Studi Kasus di Madrasah Aliyah Nahdlatul Ulama Banat, Kudus, Indonesia). Jawda: Journal of Islamic Education Management, 1(1), 14-24. https://doi.org/10.21580/jawda.v1i1.2020.6680

Kartikasari, D. (2018). Perancangan Prosedur Berbasis Manajemen Risiko pada Perguruan Tinggi dalam Rangka Migrasi ke ISO 9001:2015. Journal of Applied Accounting and Taxation, 3(2), 143-149. https://doi.org/10.30871/jaat.v3i2.868

Leontyuk, S. M., Vinogradova, A. A., \& Silivanov, M. O. (2019). Fundamentals of ISO 9001:2015. Journal of Physics: Conference Series. https://doi.org/10.1088/1742-6596/1384/1/012068

Manders, B. (2015). Implementation and Benefit of ISO 9001. https://repub.eur.nl/pub/12679/PhD Thesis_Curran_May 2008.pdf

Mardika, C. (2019). Implementasi Sistem Manajemen Mutu ISO 9001: 2015 Dalam Meningkatkan Mutu Layanan Di SMK Negeri 1 Jenangan Ponorogo. IAIN Ponorogo.

Muryadi, Soedjarwo, \& Mudjito. (2018). Implementasi Sistem Manajemen Mutu Berdasarkan ISO 9001 : 2015 Di Sekolah Dasar Katolik Santa Clara Surabaya. Jurnal Dinamika Manajemen Pendidikan, 3(1), 31-42.

Noprika, M., Yusro, N., \& Sagiman. (2020). Strategi Kepala Sekolah Dalam Peningkatan Mutu Pendidikan. Andragogi: Jurnal Pendidikan Islam Dan Manajemen Pendidikan Islam, 2(2), 224-243. https://doi.org/10.36671/andragogi.v2i2.99

Nugroho, A. W. (2017). Strategi Sekolah Dalam Menerapkan Sistem Manajemen Mutu (SMM) Berbasis ISO 9001:2015. Jurnal Manajemen Dan Supervisi Pendidikan, 1(3), 227-235. https://doi.org/10.17977/um025v1i32017p227

Rizkita, K., \& Supriyanto, A. (2020). Komparasi Kepemimpinan Pendidikan di Indonesia dan Malaysia Dalam Upaya Peningkatan Mutu Pendidikan. Jurnal Akuntabilitas Manajemen Pendidikan, 8(2), 155-164. https://doi.org/10.21831/jamp.v8i2.32362

Sugiyono. (2018). Metode Penelitian Pendidikan: Pendekatan Kualitatif, Kuantitatif dan $R \& D$. Alfabeta.

Suryana, S. (2020). Permasalahan Mutu Pendidikan Dalam Perspektif Pembangunan Pendidikan. Edukasi, 2(1).

Suwartini, E. A. (2017). Supervisi Akademik Kepala Sekolah, Profesionalisme Guru Dan Mutu Pendidikan. Jurnal Administrasi Pendidikan, 24(2), 62-70. https://doi.org/10.17509/jap.v24i2.8294

Tjalla, A. (2010). Potret Mutu Pendidikan Indonesia Ditinjau dari Hasil-Hail Studi Internasional. Seminar Nasional FKIP-UT, 3, 1-22. http://pustaka.ut.ac.id/pdfartikel/TIG601.pdf

Ulum, M. (2017). Strategi Peningkatan Mutu Sekolah Menengah Kejuruan 
Pasca Penerapan Sistem Manajemen Mutu ISO 9001:2008. Jurnal Pendidikan Ilmu Sosial, 1(1), 69-91.

Wibowo, A., \& Subhan, A. Z. (2020). Strategi Kepala Madrasah Dalam Meningkatkan Mutu Pendidikan. Indonesian Journal of Islamic Educational Management, 3(2), 108-116.

Yanto, M., \& Fathurrochman, I. (2019). Manajemen Kebijakan Kepala Madrasah Dalam Meningkatkan Mutu Pendidikan. Jurnal Konseling Dan Pendidikan, 7(3), 123-130. https://doi.org/10.29210/138700

Yasin, I. (2021). Problem Kultural Peningkatan Mutu Pendidikan di Indonesia: Perspektif Total Quality Management. Ainara Journal (Jurnal Penelitian Dan PKM Bidang Ilmu Pendidikan), 2(3), 239-246. https://doi.org/10.54371/ainj.v2i3.87

Yunus, M. (2016). Profesionalisme Guru Dalam Peningkatan Mutu Pendidikan. Lentera Pendidikan : Jurnal Ilmu Tarbiyah Dan Keguruan, 19(1), 112-128. file://C:/Users/ASUS/Downloads/Documents/2074-4241-1-SM.pdf

Zahrok, A. L. N. (2020). Implementasi Sistem Penjaminan Mutu Internal Di Sekolah Menengah Kejuruan (SMK). Jurnal Akuntabilitas Manajemen Pendidikan, 8(2), 196-204. https://doi.org/10.21831/jamp.v8i2.31288 
